\title{
ADJUDICATION
}

\section{EDWard Dumbautd}

To the Anglo-American lawyer, dissenting opinions are a familiar feature of the judicial process. Indeed, they may constitute one of its glories. The dissenting opinions of Mr. Justice Holmes ${ }^{1}$ are rightly reckoned among the treasures of our legal literature. Similarly, the separate opinion of Judge Anzilotti in the Austro-German customs union case before the Permanent Court of International Justice is described by Professor Brierly as "a contribution of permanent value to international jurisprudence". ${ }^{2}$ To many Continental European jurists, on the other hand, dissenting opinions are regarded as anomalous, if not anathema. ${ }^{3}$ How is this divergence of attitude to be explained? What, accordingly, is the status of dissenting opinions in international law, where due weight must be given to all legal systems prevailing in the civilized world? ${ }^{4}$

\section{I}

Every legal system has its procedural law, that is to say, law about law enforcement. Since in most modern communities the administration of justice is confided to impartial agencies acting under public authority, the chief subdivisions of such law deal with the organization, and with the operation, of judicial tribunals, respectively. ${ }^{5}$ The admissibility of dissenting opinions is a topic falling within the second

$\dagger$ A. B., I926, Princeton University; LL. B., I929, LL. M., I930, Harvard University; Dr. Jr., I932, University of Leyden; member of Pa. and U. S. Sup. Ct. Bars;

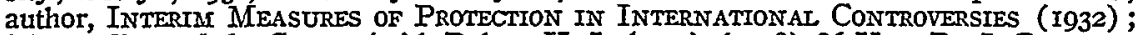
Monopolies and the Conts (with Robert H. Jackson) (1938) 86 U. oF PA. L. REv. 23I; Nentrality Laws of the United States (I937) 3I AM. J. INT. L. 306; Place of Philosophy in Intemational Law (I935) 83 U. OF PA. L. REV. 590; and other articles in various legal periodicals.

I. Dissenting Opinions of Mr. Justice Holdes (Comp. Lief, i929).

2. (I932) 3 ZT. F. AUS. OFF. RT. U. VRT. 7 I. For praise of Judge Anzilotti's qualifications as a jurist by American authorities, see Hudson, ThE PERMANent Court of INTERNATIONAL JUSTICE AND THE Question OF AMIERICAN ParTiCIPATION (I925) 278; Hughes, The World Court as a Going Concern (I930) I6 AMr. B. A. J. I5I, I54. Judge Anzilotti had been Secretary General of the Commission of Jurists which drafted the Statute of the Court, and was one of the first judges elected. He has been exceptionally diligent in his attendance at sessions of the Court, having been present at every session down to I937, when his record of perfect attendance was broken on account of illness in his family. [For this information I am indebted to Professor Manley $O$. Hudson; see his table showing attendance of judges in 25 ANr. J. INT. LAW (I93I) 433.] From I928 to I930 he was President of the Court. But in view of the high level of ability manifested by the judges of the Court, it would doubtless be too fanciful to imagine Judge Anzilotti as occupying a position of pre-eminence analogous to that of Mr. Justice Holmes.

3. Hudson, Ten Years of the World Court (I932) II For. AFr. 8r, 90.

4. Cf. articles 9 and 36 (3) of the Court Statute.

5. Dumbauld, Interim Measures of Protection in International ControverSIES (Nijhoff, I932) 8-9. 
category, which embraces matters relating to the mode in which tribunals function when exercising their jurisdiction. ${ }^{6}$

But rules of "procedure" in this narrow sense are intimately connected with those governing the organization of the judiciary, ${ }^{7}$ and both types of procedural law are shaped by and dependent upon the basic provisions of public law with respect to the function of the judicial power. ${ }^{8}$ What task does the "constitutional" or fundamental law of a given community assign to its judicial institutions? ${ }^{9}$ In particular, does it acknowledge them as an agency for the elaboration of substantive law? 10

In this connection it is impossible to ignore differences manifest in the positive law of different periods and places. One cannot declare roundly that the function of litigation is simply to apply to individual situations a foreordained, or pre-existing, substantive law. Such an assertion would imply that one particular content of procedural law must be inevitable, (a fallacious assumption akin to that made with respect to substantive law by "natural law" adherents).

Indeed, such a conception of the judicial function was unknown before the Reception of Roman Law, ${ }^{11}$ which introduced the idea of law as a general rule laid down by the lawgiver in advance, as a complete and closed system. Until that notion gained acceptance, there was no law except that which was generated in and for the concrete case submitted for adjudication. ${ }^{12}$ The middle ages had no genieral law. ${ }^{13}$ It is also notorious that primitive law did not endeavor to enforce a particular system of rules, but rather strove to appease litigants in order to deter them from undertaking violent acts of private revenge. ${ }^{14}$

6. On the distinction between procedural law in general and rules of procedure in the narrow sense, see DUMBauld, op. cit. supra note 5 , at I3, I8; CHIOVENDA, PRINCIPII DI DIRITTO PROCESSUAIE (Ig28) IOI. Gordon, The Observance of Laze as a Condition of Jurisdiction (I93I) 47 L. Q. REv. 386, 389, treats the distinction between lack of jurisdiction and error in proceeding.

7. Thus a judiciary inadequately staffed to cope with the large mass of business brought before it will tend to dispose of cases in summary fashion. $C f$. Yntema and Jaffin, Preliminary Analysis of Concurrent Jurisdiction (I93I) 79 U. OF PA. I. REv. $869,887$.

8. Schultze, Prtvatrecht und Process in IHrer Wechselbezienung (I883) xvi, refers to the public law function of adjudication ("Staatsrechtliche Funktion der Gerichtsbarkeit").

9. As to "constitutional" rules of international law, see the authorities cited in

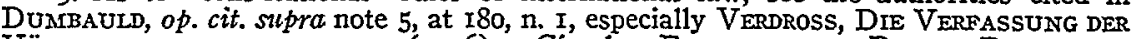
VölkerRechtsgemeinschaft (I926). Cf. also FeIlChenfedd, Public Debts and State SuCCEssion (I93i) 6oI.

ro. SCHULTZE, op. cit. supra note 8, at $2 \mathrm{I}$.

II. Id. at $2 \mathrm{I} 4$.

12. Id. at I05, IIg.

I3. Id. at 218 .

14. Pound, The Spirit of the Common Law (ig2i) 85; Cortesia di Serego, Il Processo SENza LITE (I930) IO-II; ChIOvENDA, op. cit. supra note 6, at I, 74I. Hence the mode of trial was mechanical, a "solemn experiment" designed to evoke the judgment of God rather than convince the court. 
Even today there are differences of opinion as to the true function of adjudication. While some insist that it is the just solution of disputes, ${ }^{15}$ the prevailing view regards it as enforcement of law, (attuazione del diritto, Rechtsverwirklichung), the establishment in concreto of a factual situation corresponding to the relationships ordained by law. ${ }^{16}$

Recent writers have stressed the importance of recognizing that judicial institutions are independent legal phenomena, and not mere agencies for the mechanical application of substantive law. ${ }^{17}$ More important than the formulation of a corpus juris is the establishment of a judge. ${ }^{18}$ It is more significant socially and politically that the law prescribe that disputes must be settled by judicial procedure than that it indicate in advance the precise terms of settlement. ${ }^{19}$ Judicial power is not confined within the bounds of rules. ${ }^{20}$

Two factors have tended to obscure recognition by Continental authorities of what has been said above: the bureaucratic structure of

I5. 2 Carnelutit, Iezioni Diritro Processuale Civile (ig26) i48; Cortesia DI SEREGO, op. cit. supra note I4, at $2,49$.

i6. Chiovenda, op. cit. supra note 6 , at 65 ; I Chiovenda, SAGgr di Diritto ProCEssuale CIVILE (I930) 15, 33. Most German writers stress protection of rights, rather than enforcement of law. Thus HeILWIG, KIAGRECET UND KLAGMöGLICHKEIT (I905) I. See Cortesta dI Serego, op. cit. silpra note I4, at 32 . Some American courts wrongly suppose that the judicial power cannot properly be invoked unless a wrong has actually been committed. Borchard, Judicial Relief for Peril and Insecturity (I932) 45 HARV. L. REV. 793.

I7. Guggenheim, Völkerrechtsprozessrecht und materielles Recht (I93I) II $Z_{\mathrm{T} .} \mathrm{F}$. OFF. RT. 555-576; Arnold, The Role of Substantive Laze and Procedure in the Legal Process (I932) 45 Harv. L. REv. 6r7 at 640-3. The "judicial power" is always conceived in constitutional law as a substantive power or prerogative vested in certain organs of the state, rather than as a process of enforcing certain rules. Cf. also DEGENKOLB, EINLASSUNGSZWANG UND URTEILSNORAT (1877). The distinction becomes obvious upon consideration of certain exceptional instances of adjudication: such as the conviction of one who is innocent by a court martial, in order to maintain the morale of troops; or such as the trial of Louis XVI by the Convention, regarding which one writer says: "The guilt of the king being established by the proofs already mentioned, was there any tribunal which could try him and sentence him? Was there any law which applied to his case? In the Convention these questions were debated with splendid ability. Robespierre and St. Just carried the majority with them by taking the high ground that the death of the king was a political necessity. Already condemned by being deposed, he should be put out of the way in the interest of the public peace and safety. Under this stern leadership, the Convention became prosecutor, judge, and jury-creating law as it went forward with the trial." 2 WATSON, THE STORY OF FRANCE (I899) 788.

I8. Brown and Politis, in (I922) 29 Annuarre de l'Institut de Droit IntTernaTIONAL 26: "I a notion du conflit justiciable est plus large que celle du conflit juridique. . - Si le fonctionnement de la justice est grandement facilité par l'existence de nombreuses règles de droit, il serait inexact d'en conclure que l'oeuvre de la justice est entravée par le défaut de règles de droit, ou que le conflit que ne peut être réglé par l'application d'une règle de droit est nécessairement non justiciable.

"L'expérience prouve que, loin d'avoir suivi les codes ou les rédactions de couttumes, les tribunaux les ont précédés. Elle montre encore que ce qui importe le plus pour le développement même du droit, c'est moins sa fixation que l'institution d'un juge." Cf. LAUTERPACHT, THE FUNCTION OF LAW IN THE INTERNATIONAL COMNUUNITY (I933) 424-5.

19. See Dumbauld, op. cit. supra note 5, at I74, and authorities there cited. .

20. On this topic see Dickinson, Legal Rules: Their Function in the Process of Decision (I93I) 79 U. OF PA. L. REv. 833-868. 
the judicial system with which they were familiar, and an inadequate idea of law.

To a greater extent than his English or American colleague, the Continental European magistrate considers himself as a public official, a portion of the governmental machinery of the state, instead of as the authentic expositor of the law, endowed with individuality and independence as against other organs of administration. ${ }^{21}$ The judiciary is classified by an authoritative French writer as one among many public services; ${ }^{22}$ judges dispense the commodity of justice just as another public service organization distributes electricity. The distinction between adjudication and administration tends to become obscured; there are those who declare that there is no essential difference between judicial and administrative activity. ${ }^{23}$

One must not of course overlook the existence of certain administrative aspects of judicial organization. Before adjudication proper can begin, a number of physical obstacles to presentation of the case to the court must be overcome by means of appropriate administrative arrangements. The litigant's difficulty of getting into court is especially evident when he invokes an overworked tribunal whose calendar is crowded, or when he must apply for his remedy to an international tribunal ad hoc which must be called into being for the particular case.

It has been said, besides, that law is what public officials (i. e., judges) do. ${ }^{24}$ No one will deny that the judge's task is not the same as that of an attorney or a law professor. He is not there to give abstract opinions on troublesome points of law. He is a public official, to whom parties apply only when they want him to do something for them, to use in their behalf the power which is his.

2I. Steed, The Hapsburg Monarchy (2d ed IgI4) 98. (A university professor is likewise regarded in some Continental countries as primarily a public official rather than a scientist.) The very instance of dissenting opinions (together with the doctrine of judicial review) is cited by Kraus, Modern Developments of the American and Ger-

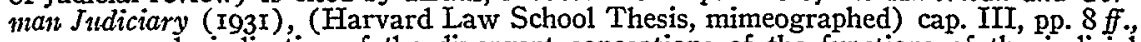
as an example indicative of the divergent conceptions of the functions of the judicial process in the polity of the two nations. Under the Nazi régime, to an extent even greater than before, the administration of justice in Germany has constituted merely a portion of the administrative activity of the state as a whole. This is shown particularly by the abrogation in German criminal law of the maxim mullum crimen sine lege. Only exceptionally, as in war-time, is there a suspicion that American courts regard themselves as upholders of governmental policy. ChafEe, FreEdon of SPEECH (I920) $58,80-4$, I25-148, 373-4; 3 BeVERIDGe, THE LiFe OF JoHN MARSHaLL (I9I9) 42, 46. Caloyanni, in (I930) 7 REv. INT. DE DRoIT PÉNAL I74, says that a judge is not a fonctionnaire.

22. 3 Jìze, Les Prtnctpes généraux du Droit Administratif (3d ed. I926) 23-26, treats of the "service public de justice civile".

23. Kelsen, Allgemeine Staatslemre (I925) 242; Cortesia di Serego, op. cit. supra note I4, at 40 . Cf. CHIOveNDA, op. cit. supra note 6 , at 293, 296, 301: I CALAMAANDRET, STUDI SUL PROCESSO CIVILE (I930) 234, 240-I.

24. Llewellym, The Bramble Buse (I930) 4. 
Now what judges do is to grant or deny certain specific legal remedies which have been requested by litigants wishing protection. ${ }^{25}$ Whether such relief-shall be granted or not, whether the protective action sought shall be taken by the court or not, depends on its decision with respect to a question of law. A judge's action must always correspond to the solution which he has given to the question of law which he has resolved. ${ }^{26}$

An administrative authority, however, though it may often have occasion to determine preliminary questions involving points of law before it takes action, is not bound to act in accordance with its determination of those questions. For the administrative official, law is only the foundation and limitation of his authority; other considerations, not of a legal nature, may properly be taken into account by him in guiding his action, and indeed are usually the preponderant factors. ${ }^{27}$ There is therefore justification for the tenacity with which English and American lawyers have resolutely refused to accept the view which obliterates the sharp distinction between judges and administrative officials. $^{28}$

Moreover a number of Continental writers are confused because they tend to think of law as a finite number of precepts. ${ }^{29}$ But "a system of law is not a sort of armoury of rules out of which the judge merely selects the one that most nearly fits the facts of the case before him; no conception of the nature of law and of the judicial function could be more misleading than that. . . . In any system of law the function of the judge is not merely to apply a rule to facts, but actually to formulate a rule which he may apply". ${ }^{30}$

Anglo-American law contents itself with the downright declaration that it is of the very essence of the judicial office to ascertain and determine what the law is. ${ }^{31}$ With perhaps keener analytical finesse, a learned Judge of the Permanent Court of International Justice distinguishes from the "judicial function" of a tribunal its "legislative

25. Dumbauld, op. cit. supra note 5 , at 4 ; Brierly in Ir Britts Yearbook of INT. LAw (I930) I28: ". . . law in action always connotes the formulation of a grievance in the shape of a claim for redress from a court, the formulation of some specific 'cause of action'. . . :"

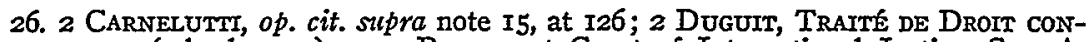
STITUTIONNEL (2d ed. I922) 322; Permanent Court of International Justice, Ser. A, No. 24 , at Io (I930).

27. Dickinson, Administrative Justice and the Suprearacy of Law in the UNITED States (I927) 24; STEIN, GRUNDRISS Des ZIVILPROZESSRECHTS UND DES KoNKURSRECHTS (Juncker ed. I928) 7 I.

28. Dickinson, op. cit. supra note 27, at 76; Arnold, loc. cit. supra note 17 , at 629 .

29. Dumbauld, op. cit. supra note 5, at I79, n. 3 .

30. Brierly, in (I930) 4 J. Royal Inst. INT. AFr. 468.

3I. Chief Justice Marshall, in Marbury v. Madison, I Cranch I37, at I77 (U. S. I803) : "It is, emphatically, the province and duty of the judicial department, to say what the law is." 
function" of "establishing what the law is on a given point". But in substance Judge Hammarskjöld does not differ with Chief Justice Marshall, since he recognizes that the so-called "legislative function" 32 is equally a part of the proper activity of a judicial tribunal. ${ }^{\mathbf{3 3}}$

The conception just developed with respect to the proper nature and scope of the judicial function is not out of place in international law. ${ }^{34}$ We conclude therefore that the task of a tribunal is to effectuate the enforcement of law (attuazione del diritto, Rechtsverzirklichung) in individual cases by ascertaining what the law is with respect to points in issue, and by acting accordingly in granting or denying the relief requested.

From this conception of the office of an international tribunal, what conclusions may be drawn with respect to the desirability of dissenting opinions in international adjudication?

So long as international arbitration was nothing more than diplomatic negotiation continued by minor dignitaries of the states in conflict, subordinate officials who had more leisure than did the framers of the agreement to arbitrate, ${ }^{35}$ the arbitral decision had little value as evidence of what international law on a given point was. It had served its purpose when it put an end to the dispute. Consequently, there can be little if any objection in such cases to the suppression of dissenting opinions. To publish them would be like publishing in a collection of statutes the minority reports, proposed drafts and amendments, and other travaux préparatoires of a legislative body.

Where the object of arbitration is simply to arrive at a solution of a particular dispute which satisfies the parties, without regard to what international law may prescribe in the premises, there is no occasion to call for publication of dissenting opinions. ${ }^{36}$

But where, on the other hand, arbitral or judicial procedure aims to reach a solution based upon the ascertainment of what international law ordains, (i.e., includes "elaboration" of law), and where, in consequence, the decision rendered is of possible importance or value as

32. In the interest of simplicity of nomenclature, it would seem better to say that

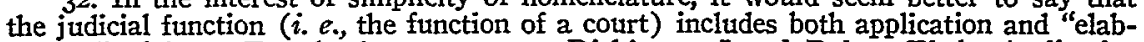
oration" of law. For the latter term see Dickinson, Legal Rules: Their Application and Elaboration (193I) 79 U. OF PA. L. Rev. I052.

33. Hammarskjöld, in (1930) $9 \mathrm{~J}$. Royal Inst. Int. Afr. 468.

34. See Dumbauld, op. cit. supia note 5, at I7, n. 4. AnzilotTr, Corso dr Diritro INTERNAZIONALE (3d ed. I928) accepts the view of Chiovenda (see note I6 supra) as to the function of procedural law for the international community. However, MoRELrI, LA SENTENZA INTERNAZIONALE (I93I) 208-9, rejects the maintenance of law or rights as the function of international jurisdiction. He lays stress on the solution of controversies, whether in accordance with law or otherwise.

35. van Vollenhoven, De Jure Pacts (I932) 4I.

36. Thus a conciliation commission need only state its recommendations, with reasons to substantiate them and show their desirability. A review of the arguments antagonistic to its conclusions is superfluous. 
authority in subsequent cases involving the same point, it then becomes desirable that dissenting opinions be made known. ${ }^{37}$

Thus it is very natural that we find dissenting opinions in English and American law, where the doctrine of stare decisis is in force. But our conclusion holds wherever judicial decisions have any value whatever as precedents; they need not be absolutely binding, as in the AngloAmerican system. That in international law great weight is attributed to previous adjudications, although there is no rule of stare decisis applicable, is indisputable. ${ }^{38}$ That the pronouncements of international tribunals are highly esteemed as evidence of what the law is needs no demonstration. Our observations apply with peculiar force in the case of a tribunal like the Permanent Court of International Justice, which is designed to build up a settled body of jurisprudence by its activity over a period of years, and thus contribute to the development of international law. ${ }^{39}$

Satisfaction to the parties as the objective of arbitration, (a hypothesis compatible with the suppression of dissenting opinions), must be distinguished from satisfaction to the parties as the test of justiciability, a doctrine which does not weaken the conclusions just stated as to the desirability of dissenting opinions in cases where a solution according to law is sought.

According to the classification of controversies just mentioned, a dispute is justiciable when a decision according to law would dispose of it in a satisfactory manner. Of course a dispute is technically "justiciable" the moment that a judicial tribunal has jurisdiction to decide it. ${ }^{40}$ States may agree to settle any sort of dispute in any way, hence, by judicial decision. ${ }^{41}$ A legal dispute is one in which both parties are seeking a solution according to a system of law conceived as existing. ${ }^{42}$ Such a decision of any dispute according to a given system of law is always possible, since the plaintiff's application for relief will be either granted or rejected. ${ }^{43}$ But the settlement arrived

37. Theoretically there is no necessary connection between the legitimacy of "elaboration" of law by the court, and the effect of judicial decisions as precedent. But both would be forbidden by a strict adherence to the Continental theory which regards adjudication as the administrative application of a closed corpus of rules, and in practice a court having the power to elaborate law is likely to regard judicial decisions as excellent evidence of what the law is, even if they are not binding authority. $C f$. articles 38 (4) and 59 of the Statute of the Permanent Court of International Justice.

38. See Hall, The Force of Precedents in International Law (I9I6) 26 INT. J. Eтн1CS I49-167; and Goodhart, Precedent in English and Continental Laze (1934) 50 L. Q. REv. 40-65, especially at 64 .

39. See, e. g., Hammarskjöld, loc. cit. supra note 33 , at 492.

40. Scort, Sovereign States AND Suits (I925) I47.

4I. Williams, Justiciable and Other Disputes (I932) 26 Anr. J. INT. LAW 3I, 34.

42. Id. at 36 .

43. As to gaps in the law, see Dumbauld, op. cit. supra note 5 , at $179, \mathrm{n}$. 3 ; VERDRoss, op. cit. supra note 9, at § 19; SOML6, JURISTISCHE GRUNDLEHRE (I9I7) 397 ff.; LAUTERPACHT, op. cit. stipra note I8, at $60 \mathrm{ff}$. 
at by that mechanical process may not be so satisfactory as an adjustment reached by legislative or other methods. ${ }^{44} \mathrm{~A}$ dispute is therefore politically justiciable when the solution reached by a judicial tribunal on the basis of existing law will give satisfaction to the parties and be accepted by them as putting an end to the dispute. ${ }^{45}$

It is thus apparent that the effect of the doctrine is merely to classify disputes by distinguishing those which may properly be referred to a judicial tribunal from those for which some other method of settlement shotild be sought. But with respect to those disputes which are thus determined to be susceptible of satisfactory solution according to law, the conclusions reached above as to dissenting opinions hold good. In the contingency in question, the parties do not seek for their dispute a solution which is satisfactory (whether or not according to law), but they declare that a solution according to law will be satisfactory. Consequently in such disputes dissenting opinions are desirable.

A similar analysis remains to be made if one accepts the doctrine regarding the nature of arbitration ${ }^{46}$ according to which international disputes cari only be settled by an agreement of the parties. The terms or content of this accord, however, may be "integrated by a third party", $i$. e., fixed by the decision of the tribunal. If one adopts this theory, it remains to ascertain in the particular case whether the arbitrator is free to make his award arbitrarily, or must decide in accordance with the applicable rules of international law. ${ }^{47}$ In the latter alternative, we are again confronted with the situation in which we have found dissenting opinions to be desirable.

We have said that when the function of an adjudicating agency is not merely to dispose of an individual dispute in any manner which will satisfy the parties, but to render an award in conformity with what it finds to be the law of the case, then dissenting opinions should be made known in order that the effect of the decision as a precedent affecting the settlement of other cases may be correctly judged and evaluated.

44. Roden, in (193I) 58 R. D. I. I. C. 770.

45. Brierly, in (r925) $4 \mathrm{~J}$. Royal Inst. INT. AfF. 234: "A dispute is justiciable when a community recognizes the decision of it according to law as really putting an end to it, and when such a mode of decision is normally acquiesced in, whether willingly or reluctantly, by the disputing parties. But these conditions are satisfied only so long as each party claims, or can be forced to content himself with, his rights according to law; they cease to be satisfied when the claim of one is for some advantage over the other, regardless of whether it may be his legal right or not."

46. Advanced by 3 AnzmotTi, Corso dr Diritto IntERnazionalle (Igr5) $40 \mathrm{ff}$., but now abandoned by him. See note 34 supra, and Morelli in (I932) II RIV. DI DIR. INT. 457-60.

47. See 3 Anzinotti, Corso di Diritto Internazionale (Igi5) 98; i id. (3d ed. 1928) at 276-7. 
In Anglo-American law where the doctrine of stare decisis attaches binding force to precedents, lawyers find dissenting opinions very helpful in determining whether a particular adjudication represents a well settled principle of law, or is of limited and weaker authority. In judging whether a decision is a procreative and desirable precedent to be extended by analogy, or one to be confined narrowly to its own facts, it is often quite useful to know whether it had the approval of a unanimous court, or was pronounced by a small majority against the dissent of the ablest and most learned judges. Again, on the other hand, the fact of dissent may show that the court's conclusion represents a settled conviction, having been reached in spite of the opposing considerations which it has had occasion to weigh carefully. ${ }^{48}$

We know that the law is a living thing. We can better gauge the direction and strength of the forces which guide its growth if we know the full and complete state of the authorities, the exact complexion of the judicial conviction.

If these arguments for dissenting opinions hold with respect to a system of law where it would be thinkable to treat all judicial pronouncements, irrespective of their rational foundation, as equally endowed with binding force by the rule of stare decisis, they apply a fortiori in international law where the authority of a decision depends solely upon its intrinsic value and the justness of the reasoning upon which it is based.

An excellent exposition of the reasons justifying dissenting opinions may be found in the minutes of the Committee of Jurists which met in Geneva, March II-I9, I929, to study the Statute of the Permanent Court of International Justice with a view to its amendment. On that occasion a proposal to prohibit dissenting opinions, presented by Judge Fromageot, was discussed and defeated.

M. Politis, who when the Statute was originally adopted had accepted dissenting opinions simply out of a spirit of conciliation, and not from conviction, had become convinced of their utility by the Court's experience in practice. He pointed out to the Committee that the function of the Court was not merely to decide individual disputes, but also to build up a body of jurisprudence by its decisions, which varied in value according as they had been rendered unanimously or not. ${ }^{49}$

Another argument advanced by M. Politis was the fact that the publication of dissenting opinions was a sort of "safety-valve" afford-

48. Waytbaugh, The Study of Cases (2d ed. I894) 49; Llewerlyn, PräJudiZIENRECHT UND RECHTSPRECHUNG IN AMERIKA (1933) 58.

49. League of Nations Document, C. г66. M. I66. (1929) V, 51. (See also Anzilotti, in P. C. I. J., Ser. D, No. 2 (Addendum, I926) 202.) 
ing an outlet for the sentiments of the losing party.50 A defeated litigant might find consolation in the fact that its views had impressed a minority of the court and had received able statement in a dissenting opinion. States would have the assurance that their arguments had not been slighted by the Court, but in the face of weightier opposing contentions had been deemed insufficient to prevail.

Not only is there this psychological advantage, but the possibility for a judge who is not satisfied with the Court's treatment of a case to express his own dissenting opinion has the effect of ensuring that careful attention will be given by the Court to all aspects of the case before pronouncing its decision. Thus a guarantee is afforded against the subconscious intrusion of political considerations. ${ }^{51}$

Dissenting opinions are indispensable in order to avoid misleading the public. ${ }^{52}$ Without the possibility for a dissenting judge to indicate his true views, the public might be led to suppose that a particular decision represented the unanimous judgment of the Court, when in fact such was not the case at all.53 Or on the other hand, more sophisticated observers, who knew that dissenting opinions were prohibited, would question the value of every pronouncement of the Court, suspecting it to have been voted by a small majority, perhaps by the preponderant voice of the President in case of a tie. In either event, the prestige and authority of the Court would suffer accordingly. To mislead students of international law and the general public by such a suggestio falsi ac suppressio veri would not only make for scientific inexactitude but would smack as well of political dishonesty. Such a policy would be incompatible with the modern tendency towards greater publicity ${ }^{54}$ and open diplomacy. Certainly if a tribunal such as the Permanent Court of International Justice, where dissenting opinions had already established themselves, were to modify its practice, public

50. Cf. the remarks of Mr. Justice Frankfurter in United States v. Morgan, 3I3 U. S. 409, 42I (194I): "In publicly criticizing this Court's opinion the Secretary merely, indulged in a practice familiar in the long history of Anglo-American litigation; whereby unsuccessful litigants and lawyers give vent to their disappointment in tavern or press."

5I. The learned Swiss jurist, Max Huber, former President of the Court, brought this point to the attention of the Committee. League of Nations Document, C. I66. M. 166. (I929) V, 52. LLEWELLYN, op. cit. supra note 48 , at 58 , points out that the possibility of criticism is a guarantee that judges will act conscientiously and diligently. (In the course of his discussion of the subject (id. at 52-6I), Llewellyn also reviews various other aspects of the scientific, legal, political and social value of dissenting opinions.)

52. Judges Moore, Anzilotti and Huber emphasize the importance of not allowing the public to obtain an impression not in accordance with the facts. P. C. I. J., Ser. $\mathrm{D}, \mathrm{No} .2$ (Addendum, I926) $20 \mathrm{I}, 223$.

53. One must also reckon with the likelihood that a judge desirous of disclaiming responsibility for a decision taken against his will might make a private disclosure of his opinion which would be injurious to the prestige of the Court. Elihu Root, loc. cit. supra note 49.

54. One might also invoke a policy in favor of the spread of science by providing the best possible documentation relating to international affairs. 
opinion, especially in America, could not fail to be unfavorably impressed. ${ }^{55}$

Against these convincing arguments only two reasons ${ }^{50}$ are advanced in favor of prohibiting dissenting opinions: (I) fear lest the prestige and authority of the Court may be weakened if it is known that able jurists on the Court hold a view at variance with that given out as the official opinion of the Court; ${ }^{57}$ (2) fear lest the absence of secrecy endanger the independence of the judges, especially the national judges ad hoc selected to sit in a particular case. ${ }^{58}$

That the authority and prestige of the Court would be weakened to a much greater extent if it were not possible for dissenting judges to express their views is amply clear after what has been said above. Without that possibility, there would not be present the "safety-valve" and guarantee of painstaking deliberation unaffected by subconscious intrusion of political considerations. Lawyers would have less faith in the jurisprudence built up by the Court, for no utterance emanating from it could be accepted as evidence of anything more than the opinion of a bare majority of the judges, made up perhaps of the weakest and least capable members of the Court, arrived at possibly by the President's casting vote. Public opinion would be suspicious of decisions "huddled up in conclave" without opportunity for criticism, ${ }^{59}$ just as it is skeptical regarding news dispatches from states with censorship curbing freedom of the press.

Moreover the publication of dissenting opinions does not really weaken the authority of the Court. Parties to the dispute are bound by the judgment as res judicata just as much whether there are dissenting opinions or not. And if an advisory opinion to clear up doubtful points of law is sought, rather than a binding judgment, it must be admitted that a truer picture of the state of the law is furnished by the Court's opinion when accompanied by dissenting opinions than when the latter are omitted. The absence of unanimity among the able

55. Root, loc. cit. supra note 49 ; Huber, P. C. I. J., loc. cit. supra note 52, at Ig8.

56. One may neglect Judge Loder's argument that the framers of the Statute intended to create a court of Continental pattern, an organism enouncing a corporate utterance of opinion. That supposition has not been substantiated by the actual trend of the Court's development. Moreover, dissenting opinions in no wise detract from the Court's corporate pronouncement; they merely add something else, the individual views of the dissenting judges. P. C. I. J., loc. cit. supra note 52, at 195 .

57. Documents concerning the action taken by the Council of the League of $\mathrm{Na}$ tions under article I4 of the Covenant and the adoption by the Assembly of the Statute of the Permanent Court (I92I) I35, 138.

58. Fromageot, loc. cit. siupra note 49 , at 50 ; Weiss, P. C. I. J., loc. cit. supra note 52 , at 204 . See also note 70 infra as to national judges.

59. Abandonment of the practice of seriatim opinions in favor of delivery of the court's opinion by one justice, even when the others were free to dissent if they wished, did not escape animadversion in America. 3 BeVErmge, The Life of JoHN MARshali (1919) 16. "An opinion is huddled up in conclave, perhaps by a majority of one, delivered as if unanimous, and with the silent acquiescence of lazy or timid associates, by a crafty chief judge. . ." 4 id. at 339. 
jurists composing the Court should be taken as indicative of the complexity and doubtfulness of the legal questions involved in the case, and not as warranting any lack of respect for the tribunal deciding them.

The second objection to dissenting opinions is likewise vulnerable. It should be noted at the outset that the independence of judges is greatest in English and American law, where dissenting opinions are the rule, and that national judges ad hoc always constitute a negligible minority of the entire Court. Even if governments tend to regard national judges as representatives of their own point of view, and would seek to visit displeasure upon a judge voting against his country's contentions, the situation would hardly be bettered by secrecy. A malicious foreign office would surely be able to find out anyhow that its judge had voted against it; the fact that his attitude was not made known publicly would merely make it more difficult for an upright magistrate to defend himself against the intrusion of politics when standing for re-election. His known honesty and ability, manifested in his published opinions, together with a high standard of public opinion, enlightened in its requirements of governments, constitute a better assurance of a judge's independence than secrecy in voting.

It might be possible however to obtain most of the advantages of dissenting opinions by publishing them without indicating the names of their authors. An analogous practice prevails in the deliberations of the Permanent Court of International Justice. When public hearings in a case are concluded, before consultation, each judge prepares a preliminary statement of his opinion, and these memoranda are circulated anonymously among the other members of the Court.

Passing from our discussion of dissenting opinions on principle to a historical examination of international practice, ${ }^{60}$ we notice that the right of an arbitrator to indicate his dissatisfaction with the award rendered was recognized by a very old usage. ${ }^{61}$ Thus the American arbitrator E. H. Kellogg stated briefly the reasons for his dissent when the award of the Halifax commission was rendered on November 23, $1877 .{ }^{62}$

In the Alabama arbitration, on September 14, I874, at the time of rendering the award, the dissenting English arbitrator, Sir Alexander Cockburn, did not sign it but he handed in a bulky paper which

60. On this subeject consult the doctrinal note in 2 Lapradelde ET Politis, Recuem DES ARBITRAges INTERNATIONAUX (1923) 922.

6I. Martens, in 2 Deuxieme Conférence internationale de la Patx, Actes ex Documents (I907) 361 .

62. I MOORE, History and Digest of International Arbitrations to which the UNTTEd States has been a Party (I898) $745,746$. 
he desired to be attached to the protocol. Count Sclopis, president of the tribunal, said that this would be done. The paper was not however annexed to the copy given to the United States, but was printed in the London Gazette, a copy of which was furnished to the United States agent. Mr. Fish, Secretary of State, said that the agent would have felt it his right and duty to object to the reception and filing of such a document, had he been acquainted with its contents. ${ }^{63}$ The unfavorable impression caused by Sir Alexander Cockburn's opinion seems to have been due to the temper and tone of his language ${ }^{64}$ rather than to any antagonism to dissenting opinions as such.

The Hague Convention of 1899 in article 52 permitted a statement of dissent, but without reasons. That article required that an award must be signed by every member of the tribunal, ${ }^{65}$ and it was felt that an arbitrator thus compelled to affix his signature to an instrument of whose terms he disapproved should be allowed to exonerate himself of responsibility by indicating his dissent at the time of signing. ${ }^{66}$

The Dutch delegate Loeff proposed to the second Peace Conference in 1907 that article 52 be changed by doing away with the right to express dissent. ${ }^{67}$ Lammasch, the famous Austrian jurist, suggested that the signature of the President and of the Secretary of the tribunal should be prescribed as sufficient to authenticate the award. Thus it would no longer be necessary for all members of the tribunal to sign, and their right to state their dissent could be done away with. ${ }^{68}$ These proposals were adopted.

The Committee of Jurists which framed the Statute of the Permanent Court of International Justice proposed to revive the I899 rule permitting a judge to record his dissent, but without giving his reasons. $^{69}$ Professor de Lapradelle had been insistent that a national judge $a d$ hoc, if he could give a dissenting opinion, would always do

63. $I d$. at 652,659 .

64. Sir Alexander's pefiections upon the arguments of the United States and the method of conducting the arbitration were resented.

65 . To the same effect article 23 of the Institut rules of $I 873$, with the proviso that if a minority refused to sign, signature by the majority with a statement of such refusal was sufficient. L'Institut DE DroIt InTERnational, Procédure Arbitrale, Article 23.

66. Pursuant to this provision, the Japanese arbitrator, Motono, dissented in the House Tax case, decided on May 22, 1905. After article 52 was suppressed in I907, Drago rendered a dissenting opinion in the North Atlantic Fisheries case in accordance with article 9, clause 2 of the compromis of September 7, I9IO. WILSON, THE HAGUE ARBITRATION CASES (I9I5) 6I-2, I92 ff. Other arbitration agreements have also provided for dissenting opinions. A number of valuable opinions have been given by the American arbitrator, Nielsen.

67. 2 Martens, loc. cit. supra note $6 \mathrm{r}$, at 360 .

68. Id. at 732; LAMMASCH, DIE LEHRE VON DER SCHIEDSGERICHTSBARKETT IN IHREM GANZEN UMFANGE (IgI4) I70.

69. Permanent Court of International Justice, Advisory Committee of Jurists, Procès-verbaux of the Proceedings of the Committee June I6-July 24, 1920, with annexes, 59r-2. 
so ${ }^{70}$ and it would be unfair if a discrimination were made and such a right given only to the other members of the Court. ${ }^{71}$

The Council of the League of Nations, however, in its meeting at Brussels adopted a number of amendments drafted by Sir Cecil Hurst, Commendatore Anzilotti and Professor van Hamel, including the present text of article 57 of the Statute. ${ }^{72}$ This text was approved by the Assembly, after a discussion in the subcommittee of the third committee where Sir Cecil Hurst strongly urged its advantages. ${ }^{73}$

In the Rules of Court of March 24, I922, provision was made in rule 62 (prescribing what the judgment must contain) for attaching to the judgment the opinions of dissenting judges, at their request. ${ }^{74}$ Upon the proposal of Judge Beichmann, similar language was included in rule $7 I$ with respect to advisory opinions. ${ }^{75}$

The Committee of Jurists had proposed to permit statement of dissent, but without reasons. The Statute authorizes dissenting opinions, but is silent with respect to the legitimacy of a mere statement of dissent without giving any reasons. The Court's practice however soon established that a simple statement of dissent was allowable, the greater including the less.

Accordingly, amendments to rules 62 and 7 I codifying that practice were adopted, in consequence of a proposal made by the Registrar, when the Rules were amended as of July 31 , I926. These provisions were incorporated, without modification, in rules 74 and 84 when the Rules were revised as of March II, I936. ${ }^{76}$

70. Id. at 53r ; of. Hill, National Judges in the Permanent Court of International Justice (I93I) 25 AM. J. INT. L. 670, 68I-2.

7r. Permanent Court of International Justice, Advisory Committee of Jurists, Procès-verbaux of the Proceedings of the Committee June I6-July 24, I920, with annexes, 743 .

72. "If the judgment does not represent in whole or in part the unanimous opinion of the judges, dissenting judges are entitled to deliver a separate opinion." Loc. cit. supra note 57 , at 42 .

73. Politis favored it; Fromageot and Loder were against it. Fernandez, recalling that in the Committee of Jurists he had favored publication of dissenting opinions, said that the new provision was certainly better than that proposed by the Committee of Jurists (which permitted statement of dissent but without giving reasons), although an argument might be made for altogether suppressing any indication of lack of unanimity. Id. at I38.

74. See P. C. I. J., Ser. D, No. 2, at 55I (I922). "The opinions of judges who dissent from the judgment shall be attached thereto should they express a desire to that effect." Article 5I of the draft rules proposed by the League Secretariat had read: "The judgment shall contain . . . (9) dissenting opinions." Id. at $266,267$.

75. Id. at 2I9. "The opinions of dissenting judges may, at their request, be attached to the opinion of the Court." See also id. at 575-576.

76. P. C. I. J., loc. cit. supra note 52, at I71, 172, 313, 315. The language of rule 62 (incorporated in rule 74 by the 1936 revision) follows: "The judgment shall contain: . The number of the judges constituting the majority.

"2. Dissenting judges may, if they so desire, attach to the judgment either an exposition of their individual opinion or a statement of their dissent." (3d Addendum, 1936, rule 74, p. I020.)

Rule 71 (which in 1936 became rule 84 ) reads: "Advisory opinions . . . shall mention the number of judges constituting the majority.

"Dissenting judges may, if they so desire, attach to the opinion of the Court either. an exposition of their individual opinion or the statement of their dissent." (3d Addendum, 1936, rule 84 , p. ro23.) 
The practice of the Court likewise sanctions dissenting opinions in connection with orders, ${ }^{77}$ and also separate concurring opinions, ${ }^{78}$ but no corresponding modification of the texts governing the Court's activity has been made.

A practice also grew up in good faith whereby certain judges did not dissent publicly, but filed secret dissenting opinions with the minutes of the Court's deliberations. ${ }^{79}$ When Lord Finlay became a member of the Court, he found this practice particularly undesirable, and a stop was put to it by a resolution of the Court. ${ }^{80}$ This resolution was adopted during the discussion of dissenting opinions which led to acceptance of the above-mentioned amendments to the Rules proposed by the Registrar.

Upon the same occasion the Court took action with respect to a proposal which had been made by Judges Loder and Weiss. They desired to eliminate the provision in rule $7 \mathrm{I}$ authorizing dissent in connection with advisory opinions. While recognizing that the right recognized in rule 62 to dissent in contentious cases was given by article 57 of the Statute and was not within the control of the Court, they nevertheless contended that the Court could and should abolish the similar right conferred by rule $7 \mathrm{I}$, an innovation undertaken upon the Court's own initiative and perhaps even violative of article 54 of the Statute which enjoins secrecy of the Court's deliberations. ${ }^{81}$

Judge Anzilotti contended that article 57 laid down a fundamental principle which should be extended to advisory procedure by analogy, like article $3^{I}$ with respect to national judges $a d$ hoc. ${ }^{82}$ Conflicting views were expressed by several other members of the Court as to whether the reasons militating in favor of dissenting opinions in contentious cases applied $a$ fortiori in advisory cases or had less force. ${ }^{83}$

77. P. C. I. J., Ser. C, No. 53, at I99 (I93I). For an example see P. C. I. J., Ser. $A / B$, No. 58 (I933). It is recognized that this practice has no basis in the language of the Statute, and is a matter over which the Court itself has full control. P. C. I. J., Ser. D, No. 2, at 24-25 (3d Addendum, I936).

78. Loc. cit. supra note 49, at 66. Judge Anzilotti's opinion in the Customs Union case, is an example. P. C. I. J., Ser. A/B, No. 4I (I93I). This practice seems clearly warranted by a proper interpretation of the language of the Statute (quoted in note 72 supra).

79. P. C. I. J., loc. cit. supra note 52, at 209 , 210.

So. $I \dot{d}$. at 222 .

8I. Id. at 283 , 195. Cf. the observations of Judge Moore. Id. at $200,201$.

82. Id. at Ig6.

83. Judge de Bustamante contended that in advisory proceedings all opinions should be expressed, since the parties sought a guide for their conduct and not a decision which they must accept. Id. at I95. Judges Weiss and Nyholm thought that an opinion accompanied by contradictory views would be of little value in contributing toward clarification of the situation. Id. at $196,197,198$. Reference was made to the practice of the British privy council when giving advice to the crown, where no variant opinions are expressed. Id. at I95. But there a body of advisers are counselling the government as to the course of policy it should pursue. The advisory opinions of the Court, however, are really a means of obtaining, without resort to obligatory arbitration, "a legal decision arrived at according to judicial procedure". Hammarskjöld, loc. cit. supra note 33 , at 487 . 
The Loder-Weiss amendment was defeated, ${ }^{84}$ and a proposal in the opposite sense made by Judges Moore, Finlay and Anzilotti was taken up. This proposal contemplated amending rules 62 and $7 x$ so as to provide that the names of all dissenting judges, as well as any opinions they might write, should be published in the judgment or opinion of the Court. ${ }^{85}$

Against this amendment, however, it was shown that the Statute in article 57 gave to a judge who disagreed with the majority only a right, and not a duty, to make known his dissent. But although the name of a particular dissenting judge could not be published without his consent, it would be possible and desirable to state in the Court's decision the number of judges making up the majority by which it had been adopted. ${ }^{86}$

This was important because some judges, ${ }^{87}$ when they disagreed with the majority, out of respect for the Court never published a dissenting opinion; whereas others regularly did. The absence of a dissenting opinion, therefore, did not necessarily mean that the Court was unanimous; and the public might be misled. ${ }^{88}$ A suggestion of Judge de Bustamante ${ }^{89}$ (that the judgment always state whether it was unanimous or not) having been criticized by Judge Anzilotti as insufficient, ${ }^{90}$ a more explicit proposal made by Judge Moore ${ }^{91}$ was adopted. ${ }^{92}$ Rules 62 and 71 were accordingly amended so as to provide that the judgment or opinion must state the number of judges forming the majority by which it has been adopted. ${ }^{93}$

Subsequently, in the Committee of Jurists studying the Statute with a view to its amendment, Judge Fromageot revived the LoderWeiss proposal of suppressing dissenting opinions, but his suggestion met with disfavor. ${ }^{94}$

Judge Hurst, on the other hand, renewed the Finlay-MooreAnzilotti proposal. Sir Cecil wished to go even further and provide that every judge who dissents must do so in a motivated opinion, giving reasons. ${ }^{95}$ He pointed out as undesirable the possibility exemplified

84. P. C. I. J., loc. cit. supra note 52, at I98.

85. Id. at 272 .

86. Id. at 20I, 2I0, 2Ir. (Anzilotti and Huber.)

87. Like Loder and Weiss. Id. at 212 .

88. Id. at 201, 223. (Anzilotti and Huber.)

89. Id. at 218 .

9o. Since one judge, without even giving reasons, could produce a situation appearing identical with that where a judgment had been adopted by the casting vote of the president in case of a tie. Id. at 222.

9I. Id. at 220 .

92. $I d$. at 223 .

93. For the text of these provisions, which in 1936 were incorporated in rules 74 and 84 , see note 76 supra.

94. Loc. cit. supra note 49 , at 50.

95. "Par une pièce motivée." P. C. I. J., Ser. D, No. 2, at 294 (2d Addendum, 1926). Judge Hurst restated during the deliberations regarding revision of the rules 
in the case relating to the Free City of Danzig and the International Labor Organization, ${ }^{96}$ where the majority was 7 to 4 , but 2 of the 4 judges voting against the majority did not publicly state their dissent. and thus remained anonymous.

However, the Hurst proposal fared no better than the earlier attempt to publish the names of dissenting judges. The Statute does not oblige a judge who differs with the majority either to state his dissent publicly, or a fortiori to write an opinion giving the grounds of his view. Would it be wise for the Court, even if it has the power to do so, to go beyond the provisions of the Statute in this respect?

\section{III}

An analysis of the contents of the dissenting opinions which have been handed down by members of international tribunals would lead us too far afield into many branches of substantive law. Suffice it to say that the judges of the Permanent Court of International Justice have very frequently had occasion to set forth their individual views. ${ }^{97}$ Dissenting opinions appear to have become a well established feature of the judicial process in international practice.

in 1936 his belief that a judge dissenting from the decision of the Court ohould give his reasons for doing so. Id., Ser. D, No. 3, at 67I (3d Addendum, 1936). Judge Anzilotti also renewed his opposition to the practice of permitting a statement of dissent without reasons. The Registrar reminded the Court that at the time the rules were previously amended, it had been deemed important to prevent misleading the public with regard to the composition of the majority by which the Court's decision had been reached. For that reason it had been concluded to make public the number of judges voting for and against the decision; and also to encourage dissenting judges to disclose how they had voted by giving them an opportunity to state publicly their dissent. Id. at 325 .

96. P. C. I. J., Ser. D, No. 2, at 294 (2d Addendum, I926). But see P. I. I. J., Ser. $B$, No. I8, at 16 (1930), where the decision is indicated as $6-4$.

97. Tabulation of 169 instances up to January $I, 1940$, in which judges thave expressed their dissatisfaction with the majority opinion would seem to indicate that the personality of judges, rather than their ad hoc or permanent tenure, governs the frequency of their dissent. Thus Judges Schücking and Rostworowski, after becoming permanent judges, continued to be frequent dissenters. A similar conclusion is reached by Hill, loc. cit. supra note 70 , at 682,683 .

The list of dissents follows: Anzilotti, r8; Altamira, 16; Rostworowski, I5; van Eysinga, r3; Hurst, Negulesco, Schücking, 9; Nyholm, 8; de Bustamante, Hudson, 6; Finlay, Rolin-Jacquemyns, 5; Fromageot, Huber, Pessoa, Urrutia, 4; Moore, Nagaoka, Römer'is, de Visscher, Wang, Weiss, 3 ; Dreyfus, Ehrlich, Erich, Guerrero, Kellogg, Loder, Papazoff, Séfériades, 2; Caloyanni, Cheng, Hammarskjöld, Hermann-Otavský, Novacovitch, Oda, Rabel, de Tomcsány, Vogt, I. Of these, as national judges: Rōmer'is, 3; Dreyfus, Ehrlich, Papazoff, Rostworowski, Schúcking, Séfériades, 2; Caloyanni, Ḣermann-Otavský, Novacovitch, Rabel, de Tomcsány, Vogt, I. 